\title{
INVESTIGATING FOR 3D TURKEY CADASTRE WITH INTERNATIONAL STANDARDS
}

\author{
M. Alkan, H.G. Sürmeneli
}

Yildiz Technical University, Dept. of Geomatics Engineering, İstanbul, Turkey (alkan@yildiz.edu.tr - hsurmen@ yildiz.edu.tr )

KEY WORDS: 3D cadastre, Data model, Turkish Cadastral system, International standards, Land administration

\begin{abstract}
:
Nowadays, a very active research area is the 3D cadastre concept. In relation, 3D Cadastre is an essential component used in a land management system which is to manage and represent layered rights digitally, restrictions, responsibilities (legal models), buildings, public services and corresponding physical models (above or below the floor surface in 3D). The 3D Cadastre has a lot of capable of collecting, storing, organising, querying, analysing and visualising very intricate details within specific standards for all over the worlds. Besides, now in Turkey, 3D cadastre is to be designing and developing with academic studies. The cadastral concept was developed for the 3D Cadastral in the early 2000s from studies related to the world countries. The first workshop was held in 2001; the second workshop was held in 2011 and 2012 in the third. Temporarily, many theoretical and practical developments have emerged in these workshops. However, no 3D cadastre is currently being performed anywhere in the world (Oosterom et al., 2011). There are several reasons why successful implementation of 3D cadastre is legal, institutional and technical. These reasons can be listed as the necessary legal documents, missing data models, lack of technology and data format deficiencies. The 3D cadastre scope should be defined as ideal in legal and institutional systems for all of the cadastral systems. While waiting for these formalities, the development of a data model for 3D cadastre is a useful method to clarify the scope of 3D cadastre. A 3D cadastral data model is the most important for the introduction of standards (INSPIRE, OGC, LADM) and a common language within the user communities of the Land Administration. In this context, some countries (Netherlands, Australia) have developed cadastral data models (ePlan, Legal Property Object Model, LADM, 3D Cadastral Data Model) to improve their cadastral systems. Although cadastral data models differ between countries, 2D is based on the basic building block of a land parcel. The existing cadastral data models were developed based on the definition of a 2D land parcel for many countries. Besides land tenure recording system with related 2D cadastral systems also. In line with the developed models, Netherlands, Australia, Croatia and Israel improved their existing cadastral systems and carried out studies in the scope of 3D cadastre. In Turkey, the 3D cadastre scope is still working for an academic site. In this study, the first section comprises of the investigation for 3D cadastral systems. Turkey studies and cadastral systems will be discussed in section 2. The scope and principles of 3D cadastre are discussed for Turkey with section 3. Moreover, the obstacles to the implementation of 3D cadastre and international standards developed within the scope of 3D cadastre are discussed and also data models developed for Turkey cadastral system with related international standards (Land Administration Domain Model, INSPIRE and ISO) in section 4. Also, finally, discussion and results were assessed in this paper.
\end{abstract}

\section{INTRODUCTION}

3D cadastral work has been continuing in scientific and institutional terms all over the world since lately 1990's. 3D cadastral studies are carried out within the framework of international standards and in the context of cadastre 2014 and 2034 declarations which are related international standards (Aien, 2013; Stoter, 2004; Alkan et al., 2018).

In all over the world, there are a lot of cadastral systems, and more situations occur for which standard 2D registration appears to be technical problems, legal and institutional. Although most legal systems provide the possibility to create a primary registration entity is mostly still a $2 \mathrm{D}$ parcel - some of the countries property rights with $3 \mathrm{D}$ boundaries. Also, the $3 \mathrm{D}$ cadastral system comprises of Rights, Responsibilities and Restrictions (RRR). For that reason, multi-level property situations are not projected on the plane, which cannot be used in the 3D data model and data schemas. Thus, within the scope of Cadastre 2034 vision, it was aimed to provide essential services expected from the cadastre such as knowing all rights, restrictions and responsibilities related to the real estates with these components, access to property and positional content and to direct the future cadastre with the developed policies, models and standards (Aien, 2013; Stoter et al., 2004, Alkan et al., 2018).
An official cadastre has not been developed to date due to legal differences such as technical and economic impossibilities in every country. Various categorizations and definitions have been made for the cadastre taking into consideration criteria such as priority purposes, types of registered rights, techniques used for collecting data. Also there are many studies shows 374 D cadastral works for some of the countries all over the world (FIG, 1995, Fendel, 2002; Stoter ve V. Oosterom, 2006; Ploeger, 2011; Stoter vd., 2012; v. Oosterom, 2013; Paasch ve Paulsson, 2014; Kitsakis vd., 2016). As a result of the studies, different topics have come up within the context of 3D cadastre. These are listed in the five main headings in FIG (Surmeneli and Alkan, 2018).

$\checkmark \quad$ Legal foundations for 3D Cadastre

$\checkmark \quad$ Initial Registration of 3D Parcels

$\checkmark$ 3D Cadastral Information Modelling

$\checkmark \quad$ 3D Spatial DBMS for 3D Cadastres

$\checkmark \quad$ Visualization and New Opportunities

In this paper, our motivation is to investigating for 3D Turkey Cadastre with based on the International Standards with the Land Administration Domain Model (LADM) within ISO 19152. Also, to contribute to the development of the land registry with LADM, this is one of the components of TUCBS project. Also, this paper presents a first stage basic model of the 
Turkey 3D cadastre to propose an international-based profile, which is the current cadastral registration and the corresponding legal requirements.

This paper is divided into seven sections. Section one is the introduction, in which the motivation and aim of this research are described. Section two describes the 3D Cadastral studies all over the world. Section three presents and explains brief information about Turkish cadastral systems. Section four comprise of the Turkey country land administration profile also based on international standards. Section five and six consists of LADM and Turkish Country profile with international standards. Finally, section five and six give to discussion and conclusion information with respectively.

\section{STUDIES For 3D CADASTRAL SYSTEMS}

From the last twenty years, there is a lot of 3D cadastral studies could be found not only an academic site but also governmental organization aspects. Also, the cadastre 2034 declaration have 3/4 D information and explanation about these topics. On the other hand, cadastre, 2014 cadastral declarations comprise of all the components of the $2 \mathrm{D}$ cadastre. As can be seen from these reports and studies, two-dimensional cadastral systems cannot respond to user's requests. Because two-dimensional cadastral systems are used for underground structures (subway, underground market, underground car parks, etc.), technical infrastructure facilities (pipelines, cables, telecommunication lines, etc.), they cannot be registered. Therefore, having a guarantee in two-dimensional systems is a problem (Karataş, 2007). Because of all these reasons, the concept of 3D cadastre has emerged, and studies have been made for its development.

According to some researchers, the 3D cadastre is not only a parcel, but also a system for digitally managing and representing layered rights, restrictions, responsibilities (legal models) and buildings, public services, and related physical models (provision of rights registered above and below). In this way, 3D cadastre facilitates the management of property rights in the real world. It also enables a wide range of applications that create demand for detailed and integrated 3D legal and physical objects. These applications provide essential information for different applications such as city planning management, land and property management (Rajabifard et al., 2012). For example, in dense urban areas, bridges and tunnels that build below or below other structures that give structures that support the land development process in particular. Besides, 3D city models (CityGML) can be integrated with Building Information Model (BIM), transport, service networks, land use and other layers of information for different applications (Aien, 2013).

When the studies of other countries within the scope of 3D Cadastre are examined, it is seen that they have similar characteristics with the studies. Although different aspects of 3D features are taken into account, depending on the nature of the cadastral systems, changes in recorded object types and other issues, the solutions implemented are not significantly different. There are regulations in Australia and Canada where detailed descriptions of how to measure and save a parcel in $3 \mathrm{D}$ are available. Also, these countries have regulations that determine $3 \mathrm{D}$ coordinates with property boundaries above or below the land surface. The Netherlands redefined ownership of land in 2007 by amending the Civil Code. Therefore, the 3D object determined by law paved the way independently for registration from the parcel.
There is a separate Cadastral for registration of Swiss underground networks, while Dutch underground networks are indicated on the cadastral map with numbers such as parcels. In Norway, registration of underground structures is not compulsory but optional. On the other hand, the Victoria and Queensland states of Australia are very interested in longstanding legislative studies on 3D immovable property in the 3D Cadastral area and research into the establishment of 3D cadastral systems following legislation. The study was conducted to convert the current cadastral database in Switzerland to 3D. The Swiss government has prepared a comprehensive plan covering the transition to $3 \mathrm{D}$ Cadastre. In China, 3/4 dimensional cadastral surveys have accelerated with pilot projects implemented in some city centres.

For this reason, within the scope of Cadastre 2034 vision, it is aimed to know all the rights expected from cadastre, to know the restrictions and responsibilities related to immovable properties with these components, to provide essential services such as access to property and location content and to direct the future. Cadastre with advanced policies, models and standards (Aien, 2013; Stoter et al. 2004).

\section{A BRIEF INFORMATION ABOUT TURKISH CADASTRAL SYSTEMS}

The goal of existing cadastre system in Turkey is: "indicating the borders of immovable properties on the land and map, depending on the cadastral and topographic cadastral map of the country by country coordinate system, and determining their legal status; thereby establishing the deed registry as assumed by Turkish Civil Law No. 4721, and building the infrastructure of spatial information system."

Cadastre in Turkey is executed as two-dimensional (2D) and parcel based. Currently, the cadastre works in Turkey are executed by General Directorate of Land Registry and Cadastre following the Cadastre Law No. 3402 and Law on Change in Cadastre Law No. 5304. Title deed registries in Turkey are recorded by the title deeds registry office and the maps by Directorate of cadastre. 2D graphic representations of many rights and limitations are available.

When we consider the land record systems in the world; we see the existence of many different systems in terms of law, organization, transactions and information management. Looking from a legal perspective, we see two types of registry systems. These are the systems of "title registration" and "deed registration" (FIG, 1995; Henssen, 1995; Dale and McLaughlin, 1999; Cete, 2008; Van Oosterom et al., 2018; Lemmen and Van Oosterom, 2013). The title registration system is a system where parcels are defined on a map or plan, with cross-references to the registries where additional information such as owner names and possession structure are recorded (Larsson, 1991; Cete, 2008). Title registration is a parcel-based system, and it is classified according to the type of records such as Europe, Torrens or British and the end product of this system is the title (Bogaerts and Zevenbergen, 2001). Deed registration is the name given to all registers, accounts and documents kept by the state in order to indicate the owners and legal statuses of immovable properties. Turkish Land Registry and Cadastral Information System (TLRCIS) is a parcel-based Land Information System. It contains geometric cadastral information and proprietary information concerning ownership (Bank and Mantarci, 2004). In our country, all transactions subject to the registry on the immovable are recorded on the title deed. Land registry in Turkey, which is a concept that encompasses all of 
the various books and documents held under public liability and it services the registration of property rights. Land registry as a whole book consists of documents and various billet that is showing all rights and obligations on real property. This documents and various billet are divided into two groups: Primary registers and auxiliary registers.

\section{THE TURKEY COUNTRY LAND ADMINISTRATION PROFILE, BASED ON INTERNATIONAL STANDARDS}

Land registry is established under the control of GDLRC for the record of immovable properties in Turkey. Land registry is a registry recorded by the state with sole liability according to real openness system in order to indicate the existing real rights on immovable properties. Title registry does not mean a single deed or record that indicates the legal status of immovable properties. Title registry is the complete file that consists of various deeds, records and documents kept indicating all rights and liabilities on the immovable properties (Fig. 8). The way to keep a title registry is indicated by Title Registry Bylaw, which was put into effect on 08.10.1930. According to article 2 of this By-law; the deeds, accounts, and documents that constitute title registry are separated into two groups, as the primary registers and auxiliary registers. First registers are the book of real property registers, the book of condominium, the daybook, official documents, and plans. Auxiliary registers are owners' register, creditors' register, seizures' register, corrections register, passing documents register journal.

\section{A BRIEF REVIEW OF LAND ADMINISTRATION DOMAIN MODEL (LADM)}

LADM is identified to be the International standard organization of ISO 19152 under technical committee TC/211 for Geographic Information/Geomatics (Lemmen et al., 2010; Tjia and Coetzee, 2013; Paasch et al., 2013; Oosterom, 2015). It was designed as a standard for all land registration and transactions within the country and countries or local and localities (Babalola et al., 2015). A standardised LADM which is covering land registration and cadastre in a broad sense (a multipurpose cadastre) that is served at least two critical goals. "(1) to provide an extensible basis for efficient and effective cadastral system development based on a model-driven architecture (MDA) in order to avoid reinventing and reimplementing the same functionality over and over again, and (2) to enable involved parties, both within one country and between different countries, to communicate based on a shared ontology implied by the model" (Van Oosterom et al., 2018).

The standardization project of LADM started from the year 2006 with a discussion between FIG and ISO/TC211 based on the report by Lemmen and Oosterom (Bablola et al., 2015; Gozdz and van Oosterom, 2018; Elia et al., 2013). Uitermark (2012) gave an overview of the paradigm aspects of the standardization process of the land administration domain model during the year 2008-2012. During this period, Harry Uitermark, Christiaan Lemmen and Peter Van Oosterom constituted the editing team of LADM (Babalola et al., 2015).

LADM has a clear relationship with common aspects of land administrations all over the world (Van Oosterom et al., 2013; Tjia and Coetzee, 2013), and it should be based on the conceptual framework of Cadastre 2014 (Kaufmann and Steudler, 1998; Lemmen et al., 2011). It should also follow the international ISO and OGC standards (Kaufmann and Steudler,
1998; Tjia and Coetzee, 2013). Many countries have considered the adoption and application of LADM to their local needs in land administration. In Europe, LADM was applied in the Infrastructure for Spatial Information (ISI) in order to prove the compatibility with INSPIRE. Besides, further investigations were examined to the integration of LADM with European Land Parcel Identification System (ELPIS) (Babalola et al., 2015; Lemmen et al., 2015).

The LADM provides as an abstract, conceptual schema with three basic packages and two sub packages (Lemmen et al., 2010, 2011; Andrade et al., 2013; Zulkifli et al., 2013). Parties (such as, people and organizations), administrative rights, responsibilities, and restrictions (such as property rights) and spatial units (such as parcels, buildings, and networks), with the latter having one subpackage that surveying and spatial representation (Elia et al., 2013; ISO, 2011). The LADM classes (Fig. 6) are prefixed by LA_ to differentiate them from other classes in the ISO geographic information series of standards (ISO, 2012).

LADM aims to improve communication by introducing standard concepts or vocabulary in the land administration domain. According to Tjia and Coetzee (2013), "this is aimed at improving interoperability between cadastral or related land information systems, thus improving the exchange of land information between local, national, and international organizations (both private and public) and information society at large."

\section{THE TURKEY CADASTRAL SYSTEM PROFILE, BASED ON INTERNATIONAL STANDARDS}

Turkey is a property class corresponding to the class admin Party Cadastral System. TC_ Property class includes ownership information about the owner of the immovable property. The primary features of the TC_Ownership class are Owner's Full Name, Father's Name, Legal Entity Name, Owner's Registration Number, Reason for Purchase, Sales Fee, Registration Date and Number Per Daily.

Responsibilities, restrictions, responsibilities of the immovable property in our system and related to the LA_RRR class. Mortgage rights and ownership and tender procedures on real estate are registered in the deed. The properties related to the properties and real estate is Rights, Type of Liability, Definition, Date of Registration and Each Payment Number. Real estate mortgage right features; Mortgage Type, Letter Order, Full Name of Requestor and Name of Case, Amount of Demand, Interest, Note, Duration, Date of Registration, Journal and Issues per Daily.

Finally, the immovable class corresponds to the LA_SpatialUnit class. According to Article 998 of the Turkish Civil Code, independent and permanent rights registered in the title deed on a separate page and independent units registered in the title deed are registered as immovable in the title deed register. The parcels and restrictions on the parcels and easement rights are recorded in the title deed. Any building on the parcel and the independent units in this building are registered in the title deed (Alkan and Polat, 2017). LADM based all diagrams relating to Figure 4 shows Turkey Surveying System. 


\section{CONCLUSION}

The General Directorate of Land Registry and Cadastre, which has a deep-rooted institutional structure, prepared the cadastral and topographic cadastral map of the country according to the country coordinate system with the Law No. 3402. Besides, the subsections of a spatial information system have been made. It was created by determining the boundaries of immovable property in land and cadastral maps. Also, the cadastral system and cadastral data have been developed with many projects.

2B cadastral parcels are the primary recording unit in Turkey, given in the text 3D / 4D situations limited rights, condominium law, is defined by the other restrictions on time-sharing and intersecting plots and are recorded (Surmeneli and Alkan, 2018). Existing cadastral data model in Turkey, all the dimensions of the land should be developed to reflect better. In this context, initiatives to ensure the integration of vision about the future development of cadastre in Turkey. The $2 \mathrm{D}$ cadastral system has been perfected with advanced e-government projects. However, the current cadastral representation represents the four-dimensional world by reducing it to two dimensions. In this case, it causes the physical world not to be fully reflected. In particular, incomplete information about the third dimension is presented because rights and objects cannot be registered independently of two-dimensional parcels and are not sufficiently associated with physical objects in the real world.

Our study aims to analyse the situation of our current cadastral system. For the development of the cadastre system in Turkey describes the actual process of the law enacted. Besides, the cadastral system was analysed with the developed e-government projects. The Turkish cadastral system has been finalized with the current laws and the developed project. However, due to the increasing population and intensive construction, the existing cadastral system is also insufficient. We need to combine our existing cadastral system with land management and developing technologies and software in a universal standard.

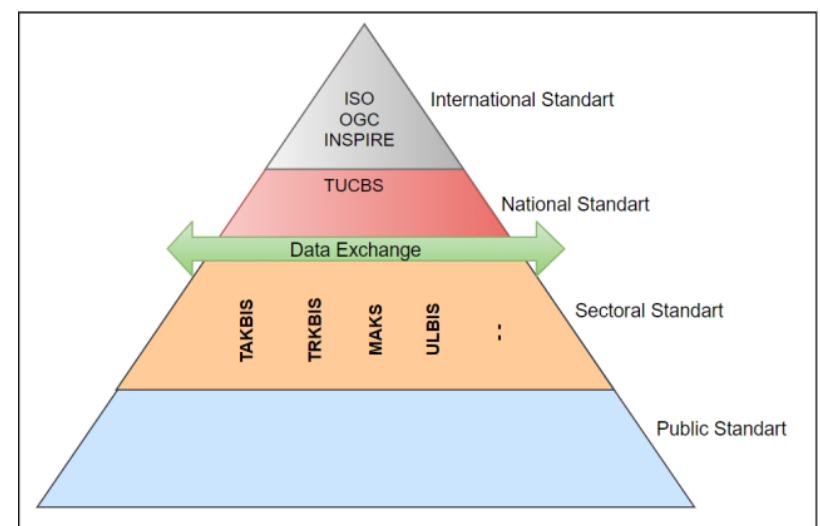

Fig. 3. Data hierarchy between standards (Erdem, 2013)

\section{REFERENCES}

Aien, A., 2013. 3D Cadastral Data Modelling. PhD Thesis, Melbourne University, Victoria, Australia.

Alkan, M., and Polat, Z.A., 2017. Design and Development of LADM-Based Infrastructure for Turkey. Survey Review 49:356, 370-385.
Alkan, M., Gursoy Surmeneli, H., Polat, Z.A., 2018. Design and Determine Cadastral and Land Management Performance of Turkey with Cadastre 2034 Vision. International Federation of Surveyors, Istanbul, Turkey.

Babalola, S. O., Abddul Rahmanb, A., Choon, T.L., 2015. A brief review of land administration domain model and its temporal dimension. Journal of Advanced Review on Scientific Research, 6(1), pp.1-15.

Cete, M., 2008. Türkiye Için Bir Arazi Idare Sistemi Yaklaşımı. $\mathrm{PhD}$. Karadeniz Technical University.

Doner, F. ve Biyik, C. , 2007a. Kadastronun Gelişimi Sürecinde Üç Boyutlu Kadastro.

Fendel, E., 2002. Registration of Properties in Strata. Report on the working sessions. International workshop on "3D Cadastres", Delft, the Netherlands,

ICSM., 2015. A Vision for Cadastre 2034

Kaufmann, J. and Steudler, D. 1998. Cadastre 2014, A Vision for a Future Cadastral System. Copenhagen: International Federation of Surveyors.

Karatas, K., 2007. Kentsel Teknik Altyapı Tesisleri, Kadastrosu ve Türkiye'deki Uygulamaların Organizasyonu, Doktora Tezi, K.T.Ü., Fen Bilimleri Enstitüsü, Trabzon.

Kitsakis, D., Paasch, J., Paulsson, J., Navratil, G., Vučić, N., Karabin., M., Tenorio Carneiro, A., El-Mekawy, M. , 2016. 3D Real Property Legal Concepts and Cadastre - A Comparative Study of Selected Countries to Propose a Way Forward, In: v. Oosterom, P., Dimopoulou, E., Fendel, E. (Eds.), Proceedings of 5th International FIG 3D Cadastre Workshop, 18-20 October 2016, Athens, Greece, pp. 1-24.

Lemmen, C. H. J., Van Oosterom, P. J. M., Eisenhut, C. and Uitermark, H. 2010. The Modelling Of Rights, Restrictions And Responsibilities (RRR) İn The Land Administration Domain Model (LADM). FIG congress 2010 facing the challenges Building the capacity, Sydney, Australia, 11-16 April 2010. Lemmen, C.H.J., Van Oosterom, P.J.M., Bennett, R., 2015. The land administration domain model. Land Use Policy, 49, 53545 .

Paasch, J. , Van Oosterom, P. and Lemmen, C. H. J. 2013. Specialization of the LADM - Modelling of non-formal RRR. 5th Land Administration Domain Model Workshop, 24-25 September 2013, Kuala Lumpur, Malaysia.

Paasch, J.M. , Paulsson, J. 2014. Legal Framework 3D Cadastres - Position Paper 1. In: van Oosterom, P., Fendel, E. (Eds.), Proceedings 4th International FIG 3D Cadastre Workshop, 9-11 November 2014, Dubai, UAE, pp. 411-416.

Ploeger, H. , 2011. Legal Framework 3D Cadastres Position paper 1, In: van Oosterom, P., Fendel, E., Stoter, J., Streilein, A. (Eds.), 2nd International Workshop on 3D Cadastres, 16-18 November 2011, Delft, the Netherlands, pp. 545-550.

Stoter, J. ,Van oosterom, P. , Ploeger, H. and Aalders, H. , 2004. Conceptual 3D Cadastral Model Applied in Several Countries. FIG Working Week 2004 Athens, Greece, May 22-27, 2004. 
Stoter, J. E. and van Oosterom, P.J.M., 2006. 3D Cadastre in an International Context: Legal, Organizational and Technological Aspects, Taylor \& Francis, CRC Press, 323 s.

Stoter, J., van Oosterom, P., Ploeger, H. , 2012. The Phased 3D Cadastre Implementation in The Netherlands. In: van Oosterom, P., Guo, R., Li, L., Ying, S., Angsüsser, S. (Eds.), Proceedings 3rd International Workshop on 3D Cadastres: Developments and Practices, 25-26 October 2012, Shenzhen, China, pp. $203-$ 218.

Tjia, D. and Coetzee, S. , 2013. Application of The Land Administration Domain Model to The City of Johannesburg Land Information System. South African Journal of Geomatics, 2(3), pp.260-79.

Van Oosterom, P. , 2015. Why and What to Standardize in Land Administration. The world cadastre summit, congress \& exhibition. Istanbul, Turkey, 20-25 April 2015.

Van Oosterom, P., Lemmen, C. and Uitermark, H. , 2013. ISO 19152:2012, Land Administration Domain Model published by ISO. FIG Working Week 2013. Environment for Sustainability. Abuja, Nigeria, 6-10 May 2013.

Van Oosterom, P.J.M., 2018. Best Practices 3D Cadastres Extended version International Federation of Surveyors, Copenhagen, Denmark, March 2018 (ISBN 978-87-92853-64-6, ISSN: 2311-8423). 
The International Archives of the Photogrammetry, Remote Sensing and Spatial Information Sciences, Volume XLII-4/W16, 2019 6th International Conference on Geomatics and Geospatial Technology (GGT 2019), 1-3 October 2019, Kuala Lumpur, Malaysia

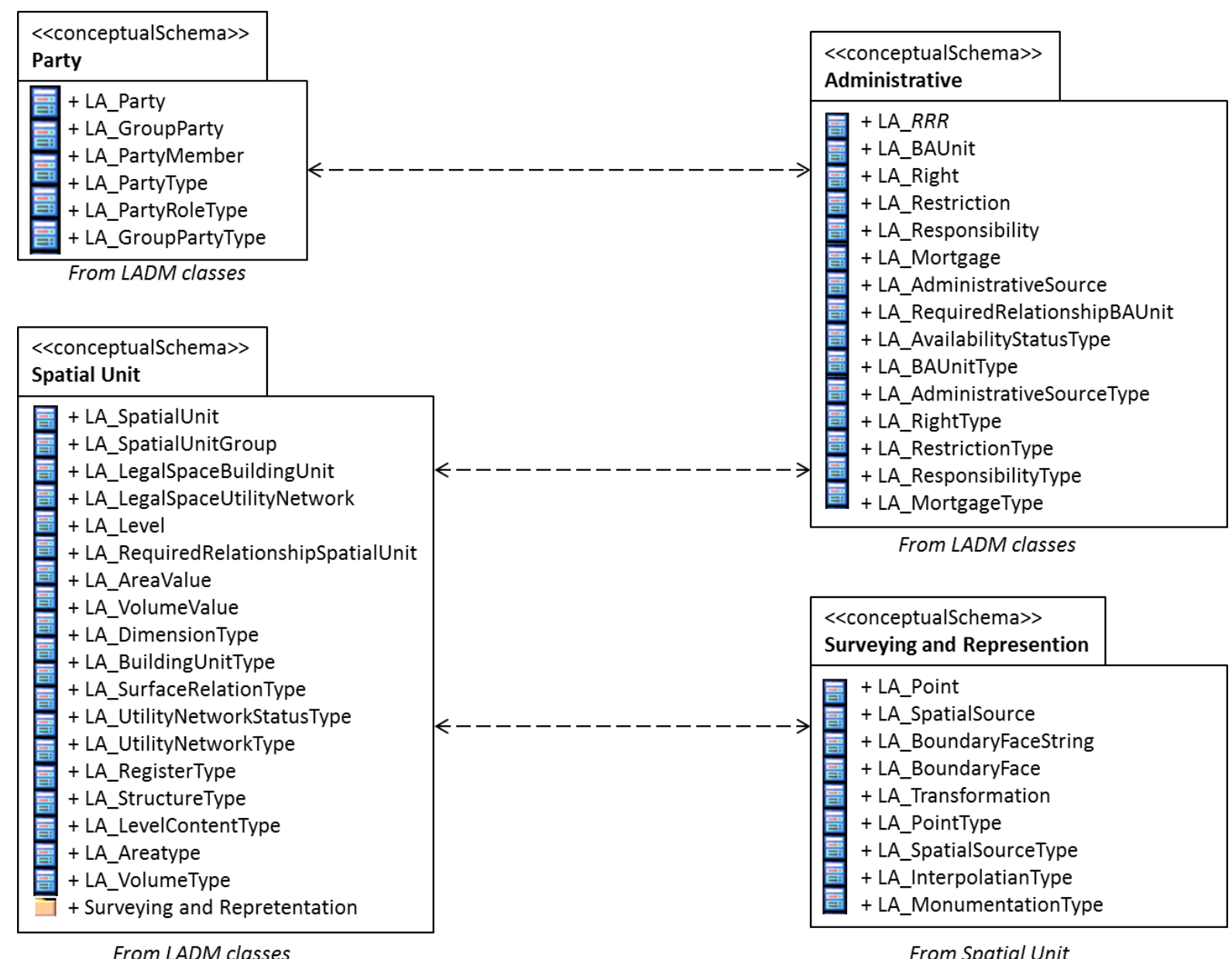

Fig. 1. The LADM overview of (sub) packages (with their respective classes) (ISO, 2012)

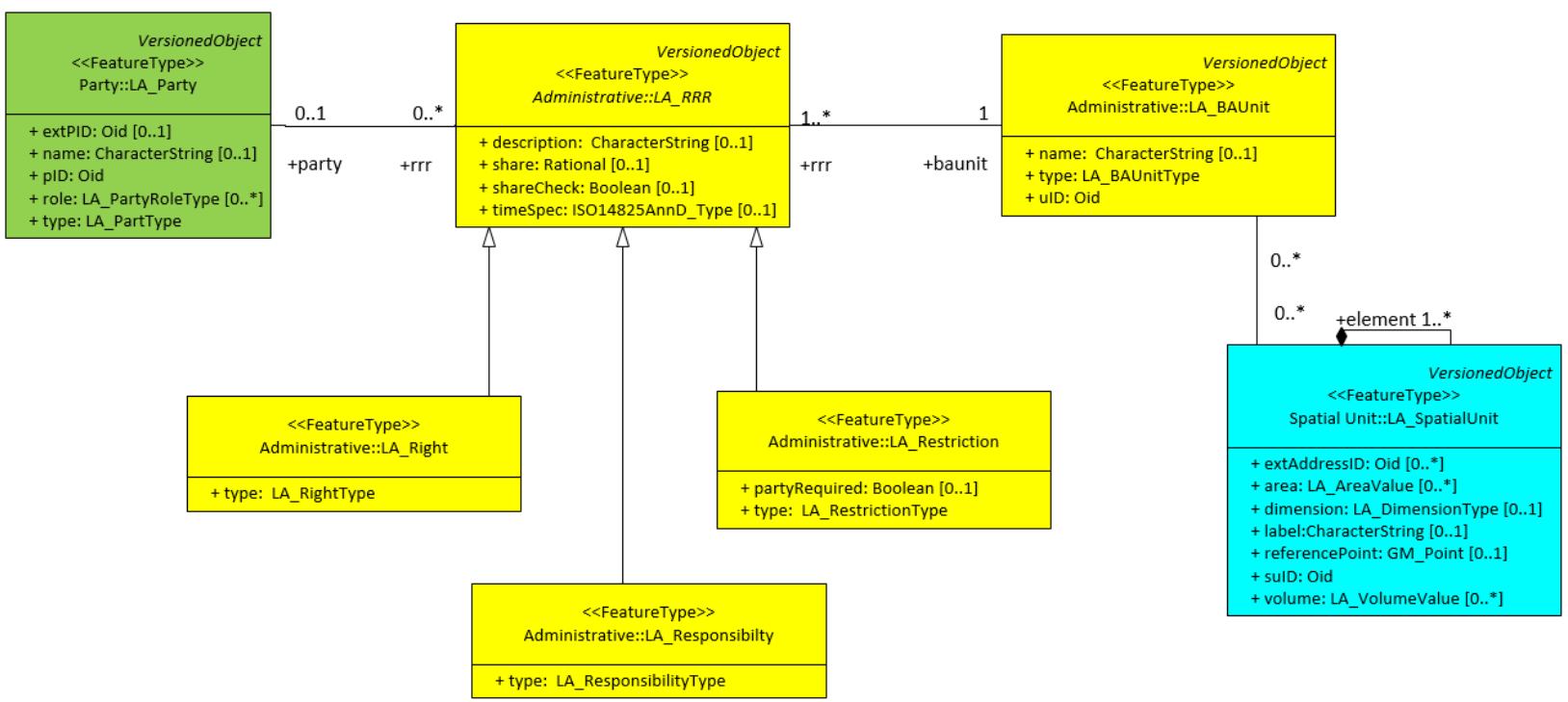

Fig. 2. LADM core classes (Lemmen et al., 2015) 
The International Archives of the Photogrammetry, Remote Sensing and Spatial Information Sciences, Volume XLII-4/W16, 2019 6th International Conference on Geomatics and Geospatial Technology (GGT 2019), 1-3 October 2019, Kuala Lumpur, Malaysia

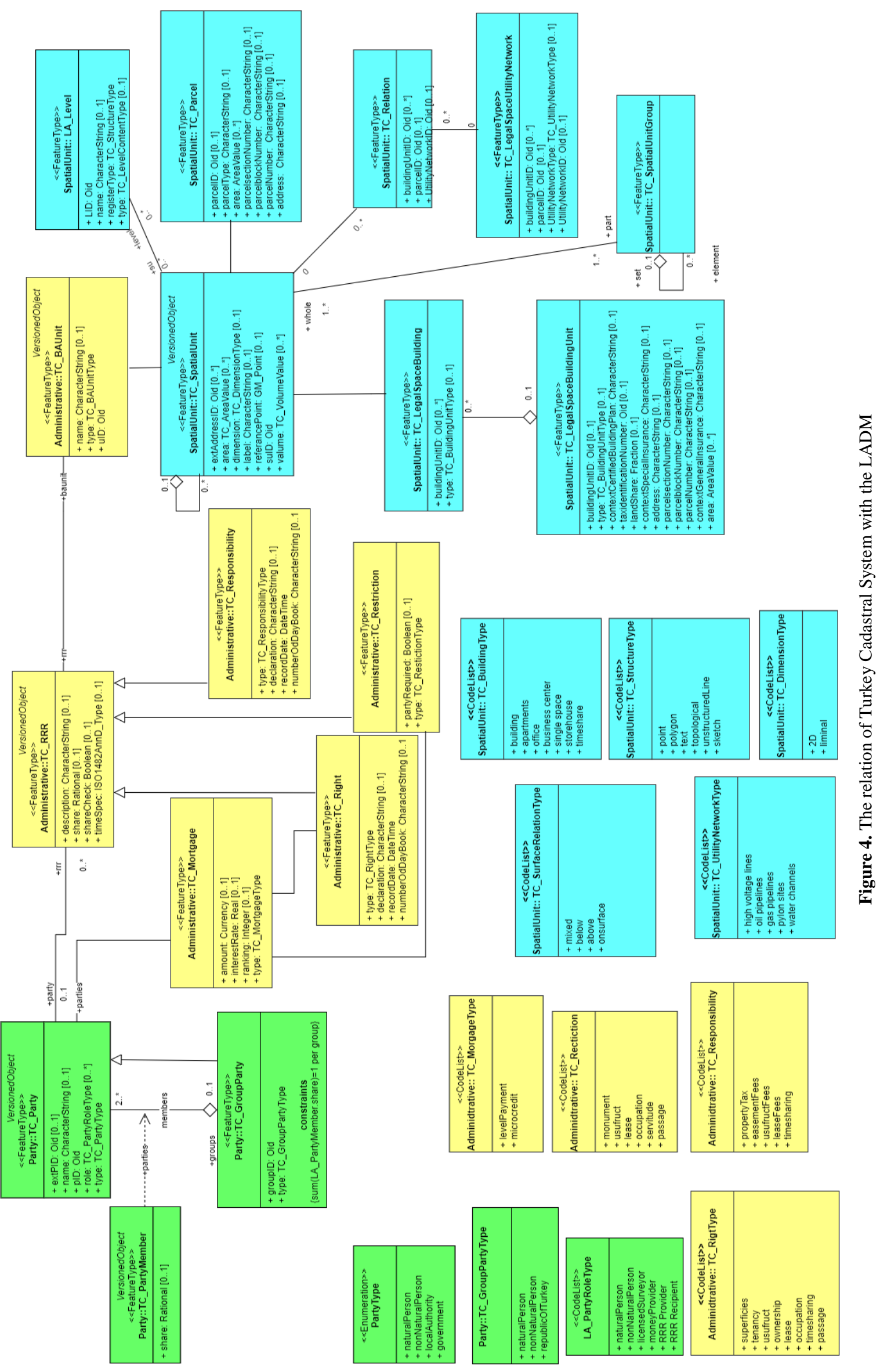

This contribution has been peer-reviewed. 